\title{
The Use of Fruity Loop Studio in Learning Tonal Music Concepts With Popular Music for High School Students
}

\author{
Pispian Rahman*, Yudi Sukmayadi \\ School of Postgraduate Studies \\ Universitas Pendidikan Indonesia \\ Bandung, Indonesia \\ *pispianrahman@upi.edu
}

\begin{abstract}
The process of learning the art of music should have been helped by the Fruity Loops application which can digitally process sound data. However, the success of learning by using Fruity Loops as a learning application has several aspects that should be noted regarding the features of the application in order to use the application effectively for learning. This article aims to discuss the level of musical progress that can be achieved, identify constraints in learning, provide feedback and important information for learning improvement. This research uses descriptive analysis method. Data collection was carried out using observation techniques, interviews, literature studies, and documentation that uses students musical works as the main data. The result of this study indicates the need for prerequisites of the teaching material scope regarding the concept of Tonal music that must be mastered well, the need for the application of teaching materials referring to application features and increasing musical abilities through auditive experiences for students in working their assignments to make popular music score.
\end{abstract}

Keywords-tonal music, popular music, fruity loops, musical intelligence

\section{INTRODUCTION}

Since the implementation of the 2013 Curriculum, Core Competencies and Basic Competencies have been established which guide the implementation of learning activities for education units and subject teachers to achieve planned educational goals with arrangements regarding objectives, content, and learning materials including Cultural Arts Study which discusses the field of the art of music with the scope of teaching materials that are explained through the subject syllabus.

In Permendikbud number 37 in 2018, there are core competences and basic competences that have been officiated. For Arts subjects for SMA/MA/SMK/MAK, they have the art subject which discusses musical art studies. In the $\mathrm{KI} / \mathrm{KD}$, it is stated that the objectives of the curriculum include four competencies, namely (1) competence in spiritual attitudes, (2) social attitudes, (3) knowledge, and (4) skills. Said competences are achieved through the intracurricular, co-curricular and extracurricular learning processes [1]

Based on the KI and KD and syllabus of Art and Culture subject for Senior High School level issued by Ministry of Education, teaching materials that were given to students of eleventh grade for basic competence of western music is Modal, Tonal, and Atonal music concepts.

In this basic competence, learners, through the learning of Art and Culture is expected have the ability to analyze the diversity of the uniqueness and beauty and be able to implement and modify concepts, techniques, procedures, materials, and media of art that has aesthetic value by paying attention to ethics and norms.

Western music concept is using a diatonic tone system in its composition, the concepts of modal, tonal, and a-tonal are known. Dieter Mack, in his book The Basic Theory of Western Music and Basic Tonal Harmony (1994) stated that: The tonal system is a music system that views sounds or tones at the same time in vertical and horizontal relationships with other tones. The tonal system views each note in harmony as if they have a certain harmonic relation. Each note has a harmonic relation framework, whether in major, minor, or a combination of the two. In tonal music, just about any melody is allowed, as long as it fits into the harmony as they walk away from and then return to their home base. Most western tonal music is based on the major and minor scales, both of which easily give off a strong tonal feeling [2].

For this reason, in providing teaching materials related to western music, it is possible to assist with using computer applications or multimedia devices in order to facilitate and assist students in mastering learning and making learning products in the form of digital-audio-based music artworks.

The use of applications in learning western music will be very useful in addition to being in line with technological 
developments in the 21 st century which are an inseparable part of the current generation. One of the computer applications that can help learning Music Arts at school is Fruity Loops Studio which will be the study of this research. In order to fulfill the learning activities of students in order to develop their abilities in the digital era, technology and informatics content can be integrated by using multimedia music in learning.

Multimedia learning is also useful in the process of learning, because it makes the learning process more interesting, more interactive, it can help the amount of teaching time to be reduced, improving the quality of students learning and the learning process can be done anywhere and anytime. Interactive multimedia is media that is designed with many integrated media and is able to interact with users with at least five elements in multimedia, namely: (1) text, (2) graphics, (3) sound, (4) animation, and (5) video [3].

The integration between the arts of music, science and modern technology has given birth to digital music technology, which can fill and answer the gaps in conventional music education in secondary schools. With digital music technology, it can provide a modern, new, and efficient classroom experience. The current development of digital music technology proves that this technology has an important developmental significance in learning music in secondary schools, therefore, music education must be integrated with modern technology to accelerate the development of music education in schools [4].

One of the substances of developing music education in schools is that it leads to an increase in the musical intelligence abilities of students as an educational outcome. According to Armstrong in Musfiroh Musical intelligence is the ability to handle musical forms. These abilities include (1) the ability to perceive musical forms, such as capturing or enjoying music and tone-patterned sounds, (2) the ability to distinguish musical forms, such as creating and converting music, and (3) the ability to express musical forms, such as singing, humming, and whistling. This means that musical intelligence is the ability to perceive and understand, create and present musical forms [5].

For this reason, as a study, this study discusses the level of musical progress that students can achieve on the relevance of the scope of the music material being taught, identifies constraints in learning and aims to find those who can provide feedback and important information to improve the implementation of learning using Fruity Loops Studio application on tonal music learning in school.

\section{LITERATURE REVIEW}

A research by Simagunsong which is the application of the Computer-based Instruction Method for learning music-making knowledge, which is presenting material, tutorials, simulations, drill, and practice and games and is built using the Macromedia Flash 8 application and the Fruity Loops Studio application. According to him, the use of this application is an alternative in overcoming several problems, such as; limited time, books that are difficult to find, spending a lot of money, and increasing learning satisfaction for users and reducing the boring atmosphere [6].

Other research that is also related to the use of the FL Studio application in learning is a research by Laksono, this study focused on the application of Fruity Loops as a learning medium in the Diploma IV Multimedia Computer study program of Stikom Surabaya. According to him, the use of Fruity Loops can spur students to be more active in creating new digital concept video and audio works, and they are expected to be able to create original work of film that has both original audio and video [7].

The application of the Fruity Loops application in learning is applied to material on the concept of Tonal music in Western Music, which at the end of the lesson produced students songs that refer to popular music genres that are familiar with adolescents. With a background of various auditive experiences of students from various rhythm patterns or styles that they recognize in modern popular music with rhythms such as; pop, rock, country, folk, waltz, rock and roll, samba, salsa, disco, and many more. In general, this musical work uses vocals, keyboards, guitars, drum sets and several other instruments.

From these various genres, students works will be observed later regarding what genres they tend to like together because peer influence is very strong among young people and adolescents in shaping musical tastes, as well as later in class participation in order for them to get musical experiences [8].

\section{METHODS}

In this study, the authors used a qualitative research paradigm, specifically, descriptive analysis. The theoretical basis is used as a guide in order to make the focus of research in accordance with evidence in the field. Data used in this research are in the form of documents of individual students assignments in the form of self-created songs with tonal music principles using the FL Studio application in the form of FL studio files, and Mp3 audio data. There were two group of twelfth grade students in this study as there are 53 work document files according to the total number of students who carried out the creation of popular music works using the FL studio application at SMA Negeri Pintar Teluk Kuantan, Riau Province.

Interviews and observations were also carried out on students and teachers in the learning process, to find out the ease and difficulty encountered by students and how much interest and motivation for learning using FL Studio.

Data analysis was carried out through data reduction, namely the process of selecting, concentrating attention, simplifying, abstracting, and transforming unprocessed data that emerged from findings in the field. FL Studio apps features delivery with tonal music teaching materials were also done in order to give description of the discussion of implementation, action taking, and the drawing of conclusion of learning purpose that can be achieved in the learning implementation. 


\section{RESULTS AND DISCUSSION}

Data that can be extracted from the results of observations of the learning process, interviews related to assignments and document analysis of students' musical works that have gone through the process of reduction or selection, concentration, focus to simplification, abstracting, and transformation of unprocessed data that acquired from findings in the field can be classified into three categories. First, the category of prerequisite material scope and its implementation steps in the application. Second, technical constraints and basic musical skills. Third, the improvement of musical intelligence and auditive experiences that can be achieved.

\section{A. Prerequisite for Tonal music concept teaching materials}

Knowledge of the steps to run the FL Studio application is not enough for students to succeed if they do not have knowledge and understanding of the basic concepts of Tonal music and popular music to be able to express musical ideas in the form of musical works.

For this reason, it can be mapped and stated what material prerequisites should be known or mastered by students before using FL Studio in western music learning for assignment of musical products in the form of modern popular songs. The material prerequisites include; (1) knowledge of symbols, interval scales on the original major and minor diatonic scales, (2) knowledge of musical elements, (3) knowledge of the concept of the triad major minor chords in the original major and minor diatonic, (4) the structure of the form or part of popular music (5) knowledge of the concept of tonal harmony (6) development of motives, melody-forming phrases and (7) chord progressions.

\section{B. The implementation of teaching materials referring to the application features}

The digital technology available to students has the potential to increase their creativity, especially in making musical works. Tasks designed that is meant to make students learn more of digital technology are certainly not trapped in the practice of understanding the operation of the application, but the students have to apply their understanding from what they have learned in the application and they must be able to produce their own work creatively [9].

Laksono, in his article described the features of Fruity Loops, the operation steps of Fruity Loops, such as: Drum Arrangements, Composition and Syntesizer Arrangements, Composition and Arrangement in the form of intro (FL Key), Making Bass Arrangements, Making Composition and Arrangements in the form of a Melody, Composition and Arrangement in the form of Playlists, Equalizer Arrangements [7].

Appreciate western music works with the Tonal concept with the popular music genre as a reference as the initial stage of learning. This is done as part of apperception to provide an auditive experience in observing and recognizing song structures in popular music works.

Song structure is the arrangement of parts in a song or popular music in order to produce a meaningful song composition. Therefore, a song has a form/structure which usually consists of an intro, verse, bridge, chorus, chorus/chorus, interlude, ending/coda [10].

The following is presented about the application of tonal music concept teaching materials in using the digital Fruity Loops studio application.

1) Tempo: Tempo setting in the Fruity Loops Studio application is the first step that had to be taken when the application has been run, while the recommended tempo range is 60 - $100 \mathrm{bpm}$ (beats per minute). In this process, students are required to feel and adjust the tempo speed of the musical ideas they have planned. The tempo at fruity loops studio show in figure 1 .

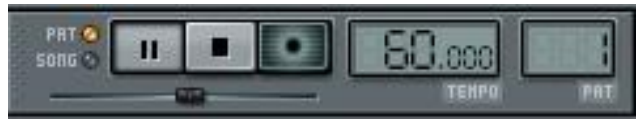

Fig. 1. Tempo at fruity loops studio.

2) Notation and rhythm values: Arranging for a percussion instrument or drum set that are available in the application allow students to apply an understanding of the short length of sound or note value and tie the musical experience of rhythm or style to popular music genres. Students will be required to pay close attention to the sound of each drum set with the rhythm setting and the length of the hi-hat, snare drum, tom, bass drum, crash as desired. The note values in graphing on fruity loops studio show in figure 2 .
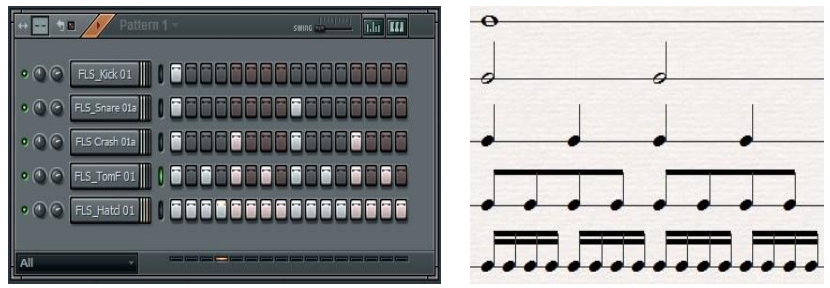

Fig. 2. Note values in graphing on fruity loops studio

3) Piano (FL Keys), chords and harmonies: In this channel, students are given an understanding and auditive experience about piano instruments, tone areas, formulas for terts intervals, quints in triads or major and minor chords which are the basic building blocks of harmony principles in tonal music. Example: chords on the diatonic scale of $\mathrm{C}$ Major (C, Dm, E, Em, F, G, Am). Writing on the piano roll for chords on the piano (FL Keys) show in figure 3. 

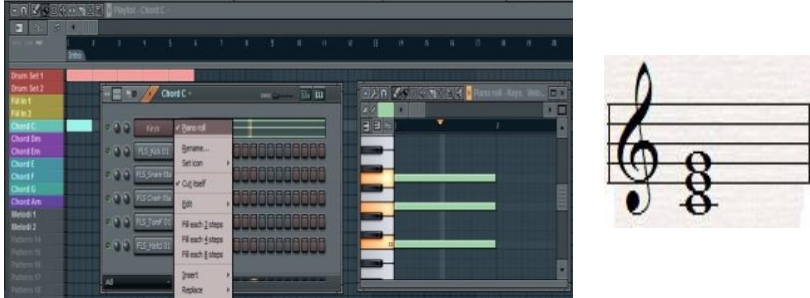

Fig. 3. Writing on the piano roll for chords on the piano (FL Keys).

4) Root Bass (BooBass): The root tone or root in tonal music is important to give a strong impression of chord progressions so that in this channel students are given an understanding and auditive experience of the low pitch area on the bass, as well as the general principles of one of the basic notes used from triads or chords. Although only one pitch in auditory tone of this bass very influential in a work of popular music. Piano roll writing for root bass (BooBass) show in figure 4.
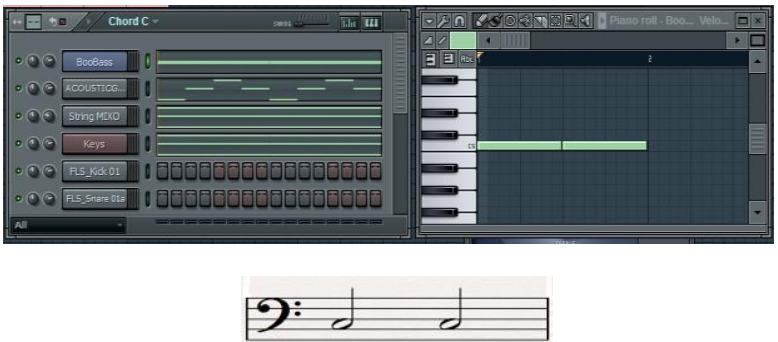

Fig. 4. Piano roll writing for root bass (BooBass).

5) Melody (motives, phrases and scales): Compiling the melodies is the most crucial part to assess the musical abilities of students, such as; understanding of tonal music, knowledge of popular music auditively, even their solfeggio skills as well. Students will be challenged to be able to pour out the melody that is in their creative thoughts, through the development of motives so that they become phrases even in simple techniques, such as repetition techniques, sequences, modifications and others. Choosing a chord progression that is in accordance with the idea of a melody must also be considered, especially regarding the scales that really determine the notes that are created to build a melody. Writing piano roll melodies with piano sounds (FL Keys) in figure 5.
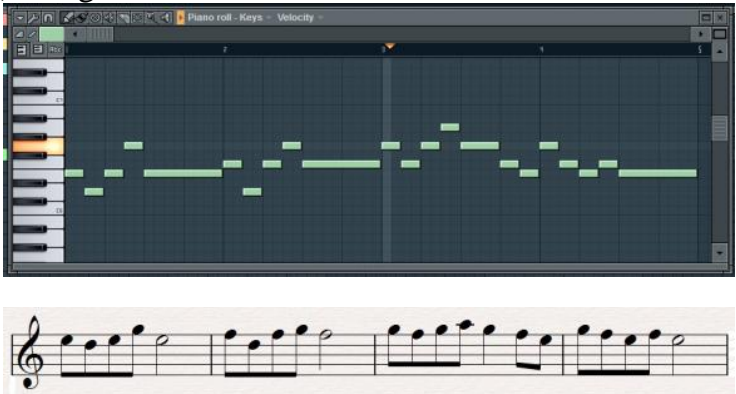

Fig. 5. writing piano roll melodies with piano sounds (FL Keys).
6) Arrange Songs on the Playlist: This feature is the final part of completing a musical work. Students can arrange all the channels, patterns, which they previously made into a complete part and can be played as a whole referring to the form and structure of popular music. Playlists of channels or patterns of whole musical works show in figure 6 .

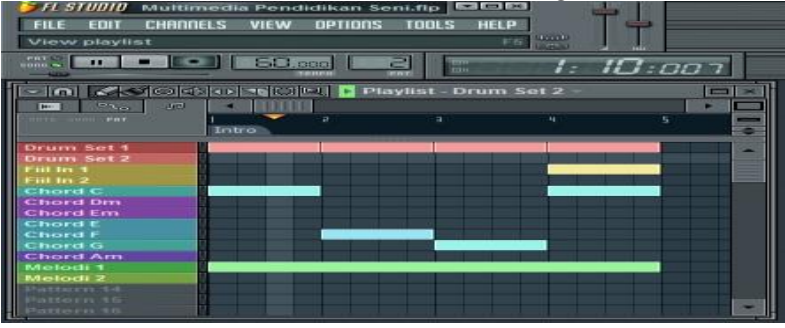

Fig. 6. Playlists of channels or patterns of whole musical works.

\section{Improved musical abilities through auditive experiences}

The use of the fruity studio application in music learning, especially for assignments to make the musical work is beneficial for teachers and students, especially with the limited facilities of musical instruments at school. This application facilitates its users in sounding different sounds that resemble the original musical instrument without having to play the musical instrument directly which is less effective and efficient in learning especially with respect to test the concept of music theoretically with feel of auditive music.

The process of delivering music learning materials known in tonal music concepts such as, tempo, rhythm, chords, melodies, motives, phrases, scales and others are directly delivered to the learner. In order to increase the students' musical intelligence in the context of theoretical basis or auditive.

Through students' understanding of musical elements or elements such as rhythm, melody, harmony, musical form and style, and expression as part of the musical experience, it will also instill awareness of the need for music and music for students' lives [11].

Learning music does emphasize students how to learn through higher order thinking. Thus, music education is an extraordinary way and offers a unique way of knowledge that is not available through other disciplines. Because music is the most direct way to think. Listening to music auditively demands critical hearing by comparing what is heard by the ears and what is in the mind of the listener, and analyzing the sound critically [12].

Thus, through learning music using the Fruity Loops studio application, it is believed that it can make it easier to improve musical intelligence for students at the high school level, at least by learning using this application student can; (1) strengthen musical understanding related to musical elements. (2) creating and understanding melody and harmony in the concept of tonal music (3) improving musical abilities auditively. (4) producing non-classical genre songs (western 
music) in the form of audio data (5) proficient in using FL Studio applications which is useful for creating music needed in everyday life.

\section{CONCLUSION}

The conclusion that can be drawn in this study is that the use of the Fruity Loops Studio application in learning to create western music can provide convenience in providing deep knowledge and understanding of the concept of tonal music while providing an auditive musical experience to students. So that it can improve musical intelligence, including. (1) ability to perceive musical forms, (2) ability to distinguish musical forms, and (3) ability to express musical forms.

For its application in creating popular music using Fruity Loops Studios, it is necessary to pay attention to the material prerequisites for the basic concepts of music that students must understand, including: (1) symbol knowledge, interval scales on the original major and minor diatonic scales, (2) knowledge of musical elements, (3) knowledge of the concept of the triad major minor chords in the original major and minor diatonic, (4) the structure of the form or part of popular music (5) knowledge of the concept of tonal harmony (6) development of motives, melody-forming phrases and (7) chord progressions. In addition, in its application in schools, teachers must also pay attention to the availability of adequate multimedia devices for each student to operate the application.

\section{REFERENCES}

[1] Permendikbud RI Nomor 37 Tahun 2018 Tentang Perubahan atas Permendikbud Nomor 24 Tahun 2016 Tentang KI dan KD Mata Pelajaran pada Kurikulum 2013 Pada Disdakmen. Jakarta: Kementrian pendidikan dan Kebudayaan. 2018.
[2] Kemendikbud, Seni Budaya Kelas XI: Buku Guru. Jakarta: Pusat Kurikulum dan Perbukuan, Balitbang, 2017.

[3] Daryanto, Media Pembelajaran: Peranannya Sangat Penting dalam Mencapai Tujuan Pembelajaran. Yogyakarta: Gava media, 2010.

[4] P. Zhang and X. Sui, "Application of Digital Music Technology in Music Pedagogy," International Journal of Emerging Technologies in Learning (iJET), vol. 12, no. 12, 2017.

[5] Musfiroh, Takdiroatun. Pengembangan Kecerdasan Majemuk. Jakarta: Universitas Terbuka, 2008.

[6] M.A.L. Simangunsong, "Aplikasi Pembelajaran Pembuatan Musik Menggunakan Fl Studio Dengan Metode Computer Bassed Instruction," Jurnal Riset Komputer (JURIKOM), vol. 3, no. 6, pp. 90-94, 2016.

[7] Y.T. Laksono, "Penerapan Aplikasi Fruity Loops sebagai Media Pembelajaran Penciptaan Komposisi dan Aransemen Tata Suara,” Jurnal Studi Komunikasi (Indonesian Journal of Communications Studies, vol. 1, no. 3, 2017.

[8] R. Colwell and L. Davidson, "Musical Intelligence and the Benefits of Music Education," NASSP Bulletin, vol. 80, no. 583, pp. 55-64, 1996.

[9] S. Wise, "Secondary school teachers approaches to teaching composition using digital technology," British Journal of Music Education, vol. 33, no. 03, pp. 283-295, 2016.

[10] R. von Appen and M. Frei-Hauenschild, Markus, AABA, Refrain, Chorus, Bridge, Prechorus Song Forms and their Historical Development. In : Samples. Online Publikationen der Gesellschaft für Popularmusikforschung/ German Society for Popular Music Studies e.V. Ed. by Ralf von Appen, André Doehring and Thomas Phleps, vol. $13,2015$.

[11] H.Y. Wicaksono, Kreativitas dalam Pembelajaran Musik. FBS Universitas Negeri Yogyakarta, Cakrawala Pendidikan, Th. XXVIII, No.1. 2009.

[12] S. Snyder, "Developing musical intelligence: Why and how," Early Childhood Education Journal, vol. 24, no. 3, pp. 165-171. 1997. 